Free movement of labour in Europe: a solution for better labour allocation?

Béla Galgóczi and Janine Leschke

Working Paper 2015.06

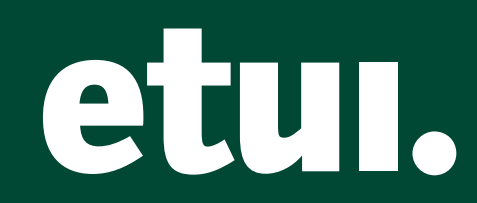




\section{Free movement of labour in Europe: a solution for better labour allocation?}

Béla Galgóczi and Janine Leschke

Working Paper 2015.06

european trade union institute 
Dr Janine Leschke is an associate professor in the Department of Business and Politics at the Copenhagen Business School, Denmark, jle.dbp@cbs.dk

Dr Béla Galgóczi is a senior researcher at the European Trade Union Institute, Brussels, Belgium, bgalgoczi@etui.org

Brussels, 2015

๑ Publisher: ETUI aisbl, Brussels

All rights reserved

Print: ETUI Printshop, Brussels

D/2015/10.574/37

ISBN: $1994-4446$ (print version)

ISBN: 1994-4454 (electronic version)

The ETUI is financially supported by the European Union. The European Union is not responsible for any use made of the information contained in this publication. 


\section{Contents}

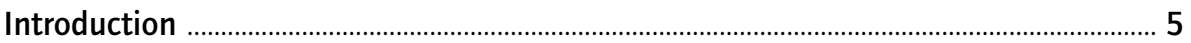

1. Free movement of labour - a core value of the EU ……………........................... 7

2. Impact of the economic crisis on cross-border labour mobility ........................... 9

2.1 Main trends of intra-EU labour mobility with special attention

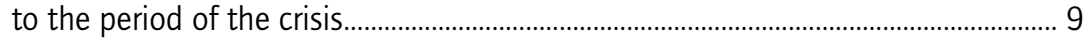

2.2 Sending-country labour-market performance and impact on mobility ................. 12

3. EU10 migrant labour and skills mismatch:

brain drain, brain gain and brain waste .............................................................. 16

3.1 Skills composition of EU10 workers and nationals.................................................. 17

3.2 Sectoral distribution of EU10 labour in major EU15 receiving countries ........... 19

Conclusions and policy recommendations …….............................................................. 25

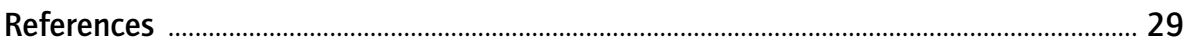





\section{Introduction}

The debate on the free movement of labour within the EU has gained new momentum in the wake of the economic crisis. The European Commission has time and again promoted intra-EU labour mobility as a major contributor to the better functioning of European labour markets as, for example, the European Job Mobility Action Plan (European Commission 2010) puts it. Intra-EU mobility can raise overall EU GDP if it improves labour allocation by better matching workers' skills and job vacancies, as a 2011 report of the European Commission stated (European Commission 2012). A recent paper by the European Commission (Arpaia et al. 2014) finds empirical evidence for increased responsiveness on the part of labour mobility in adjusting to asymmetric demand shocks in integrated economic areas and monetary unions.

On the other hand, concerns about increasing labour mobility are mounting in a number of member states and populist parties are trying to capitalise on these fears. So, is free movement of labour in Europe a problem or is it a solution in terms of contributing to better labour allocation? While we believe that cross-border labour mobility has great potential, its beneficial effects do not come automatically. The tensions and perceived problems attached to it also reflect various malfunctions. Building on updated empirical evidence using special extracts of aggregate European Labour Force Survey (EU LFS) data, and on earlier findings of an edited volume (Galgóczi, Leschke and Watt 2012) in this working paper we characterise the main trends in post-enlargement east/west intra-EU labour mobility. The main focus will be on how different population groups, nationals, EU8 and EU2 ${ }^{1}$ migrants have been affected by the turbulent processes of opening up national labour markets and subsequently by the crisis. Taking stock will allow us to discuss the potential of the free movement of workers with regard to better labour allocation and to make policy recommendations in that connection.

In Section 1 we address the institution of the free movement of labour and its challenges. In Section 2, we use the most recent data from special extractions of the aggregate EU LFS to show European trends in cross-border labour mobility during the crisis, also taking into account labour market outcomes for migrant and local workers. In Section 3, we assess the skills/occupation mismatch by reviewing the existing evidence from EU LFS data for skills

1. The EU8 are the central and eastern European countries that joined the EU in 2004, the EU2 are Bulgaria and Romania, which joined in 2007. 
composition and branch distribution for $\mathrm{EU}_{1 \mathrm{O}^{2}}$ migrant workers. The paper concludes with an evaluation of the costs and benefits of intra-EU cross-border labour mobility with regard to sending and receiving countries.

2. We shall use EU10 to refer to the EU8 and the EU2 together. Although Cyprus and Malta also joined the EU in 2004, the limitations on the free movement of labour did not apply to them and they are not discussed here. 


\section{Free movement of labour - a core value of the EU}

The European project of ever closer integration has come under pressure in the wake of the financial crisis and the following euro-zone crisis. Popular support for Europe is on the wane, as indicated by the upsurge of populist parties in the last European Parliament elections and a number of national electoral campaigns. This represents a significant question mark with regard to the free movement of labour.

The EU has long been perceived as a convergence machine supported in particular by economic integration in the single market but on a more practical level also by the European Structural Funds. However, this trend has been broken with the crisis and instead divergence in areas such as the economy, labour market and politics has increased to levels not seen before. Increased labour mobility is seen by some as a solution to the growing divergences in Europe; a supplementary adjustment channel, as the European Commission (2012) formulates it. At the same time, an increasing number of EU citizens from other countries in national labour markets is causing more and more tensions in a number of member states, often taken advantage of by populist parties and increasingly also by parties of the political centre.

Over the past decade, EU15 countries have gradually and successively opened up their labour markets to workers from central and eastern European countries (EU8), which joined the EU in 2004; Germany and Austria alone made use of the entire seven-year transition period for free movement of labour. In contrast, nine countries made use of the full transition period up to 1 January 2014 for workers from Bulgaria and Romania (EU2), which joined in 2007.

While in accession countries, 'free movement' was seen unanimously as a fundamental right, in the EU15 countries accession was preceded by intensive and at times controversial debates. Questions were raised about the potential size of immigration flows and whether countries should immediately open up their labour markets fully, permitting unhindered labour mobility, or whether existing restrictions should be maintained for the foreseen transitional periods. These debates have to be seen in view of the very wide economic and social differences - in particular, wage differences - and against the background of a discussion about the role of migrant labour in advanced economies and societies, in some cases rising populism and xenophobia, and, at least in some countries, high unemployment.

A geographical redirection from historical migration patterns and preenlargement labour flows took place towards EU15 countries that opened up 
their labour markets right after enlargement and at the same time enjoyed favourable labour market demand conditions (Galgóczi, Leschke and Watt 2009; Kahanec and Zimmermann 2010). Thus, while the overall impact of post-enlargement cross-border flows was less important than foreseen, migration to certain countries - notably the United Kingdom and Ireland and, with regard to EU2 migrants, Italy and Spain (Holland et al. 2009) - was far greater than had been forecasted (for a critical review see Dustmann et al. 2003; Heinz et al. 2006). As we will illustrate in the next section, the impact of the crisis on receiving countries led to some diversion here. Moreover, transitional measures seem to have shifted the balance between different mobility channels. Where employment was restricted by transitional measures functional equivalents of labour mobility, including posting of workers (IDEA Consult ECORYS Netherlands 2011) and bogus self-employment under the free movement of services (Cremers 2011), increased (for evidence, see Galgóczi, Leschke and Watt 2012: 23ff; Fellmer and Kolb 2009: 134f). An important new trend of post-2004 labour mobility is the fact that migrants from low wage countries generally have comparably high educational profiles, also in relation to nationals in the receiving countries; this will be addressed in detail in Section 3 . 


\section{Impact of the economic crisis on cross- border labour mobility}

Severe recessions have historically had a negative impact on net migration, and particularly labour migration, but only in the short term (OECD 2009: 63). Accordingly, the European Integration Consortium (2009: 53) suggested that the current financial crisis may reduce short-term migration substantially as the most important pull factor tends to be employment opportunities in destination countries (Galgóczi, Leschke and Watt 2009). Simulations by Ahearne et al. (2009: 34-39) focussed on the labour market situation in sending countries, as a push factor. For the countries that have been less affected by the crisis (Czechia, Poland, Slovakia and Slovenia) migration outflows were projected to be lower than if the crisis had not hit, whereas hardhit countries such as the Baltic states were expected to experience a rapid expansion of emigration due to the worsening of their position relative to the EU15. Indeed, labour migration within the EU appeared to be particularly sensitive to economic changes, whereas family and humanitarian immigration was less sensitive to economic conditions (OECD 2012).

The following section uses the most recent aggregate data from the European Labour Force Survey to shed some light on the latest trends in intra-EU labour mobility and the labour market impacts of the crisis. We show results for selected receiving countries. ${ }^{3}$

\subsection{Main trends of intra-EU labour mobility with special attention to the period of the crisis}

With the exception of a few EU15 countries - namely Ireland, Italy, Austria, the United Kingdom Spain and Luxembourg, which displayed shares of EU1O employment in total employment of more than 2 per cent in 2013 - intra-EU mobility is still relatively low from a receiving country perspective, as Table 1 illustrates. Differences between EU15 member states in terms of their EU10 employment share are huge. Although it was severely affected by the economic crisis, Ireland has by far the highest share of EU10 employment as a share of total employment (7.23 per cent in 2013). France has the lowest share (0.24

3. The choice of countries reflects the size of the receiving countries (for example, the inclusion of France despite comparatively small EU10 migrant stocks), their importance in terms of migration trends from EU10 countries (for example, the inclusion of Austria and Ireland) and the broad coverage of their welfare regimes (for example, the inclusion of Denmark). 
per cent), with Portugal, the Netherlands and Sweden also having comparatively low shares of EU10 employment.

Changes over the years also reveal quite different dynamics by country, while on EU27 average the share of EU10 labour more than doubled between 2005 and 2013; in Denmark the increase was sevenfold, although still at a relatively low level. Italy, Belgium and the Netherlands also saw substantial and steady increases. For Spain and for Ireland the impact of the crisis on labour mobility is clearly visible in the figures. This is not the case for Italy - despite also having been relatively strongly affected by the economic crisis - rather the contrary.

From a sending-country perspective the magnitude of outward migration also shows great differences. EU8 and EU2 outflows between 2004 and 2009 were -1.8 per cent and -6.3 per cent, respectively, on average, with the highest outflows recorded for the Baltic countries, Poland, Bulgaria and in particular Romania (-7.3 per cent) (Holland et al. 2011; Ambrosini et al. 2011; Dølvik and Eldring 2008).

Table 1 Share of EU10 employment in total employment -development 2005-2013 (from largest to smallest in 2013)

\begin{tabular}{|l|r|r|r|r|r|r|r|r|r|}
\hline & 2005 & 2006 & 2007 & 2008 & 2009 & 2010 & 2011 & 2012 & 2013 \\
\hline IE & $:$ & 5.79 & 7.98 & 8.27 & 7.58 & 7.11 & 7.19 & 7.27 & 7.23 \\
\hline IT & 0.88 & 1.16 & 1.30 & 1.91 & 2.50 & 2.97 & 3.17 & 3.36 & 3.52 \\
\hline AT & 1.81 & 1.64 & 1.76 & 1.89 & 1.95 & 2.03 & 2.28 & 2.64 & 2.98 \\
\hline UK & 0.63 & 1.13 & 1.65 & 1.95 & 2.03 & 2.35 & 2.75 & 2.79 & 2.87 \\
\hline ES & 2.13 & 2.45 & 2.82 & 3.13 & 3.01 & 2.79 & 2.64 & 2.50 & 2.61 \\
\hline LU & 0.30 & 1.18 & 1.25 & 1.35 & 1.33 & 1.54 & 2.01 & 2.25 & 2.29 \\
\hline DE & 0.75 & 0.83 & 0.91 & 0.98 & 1.07 & 1.06 & 1.23 & 1.42 & 1.62 \\
\hline EU27 & 0.61 & 0.80 & 0.98 & 1.14 & 1.21 & 1.31 & 1.42 & 1.48 & 1.57 \\
\hline BE & 0.30 & 0.30 & 0.51 & 0.63 & 0.77 & 1.10 & 1.25 & 1.27 & 1.53 \\
\hline DK & 0.16 & 0.19 & 0.34 & 0.30 & 0.49 & 0.61 & 0.75 & 1.17 & 1.29 \\
\hline GR & 1.06 & 1.09 & 1.13 & 1.23 & 1.51 & 1.48 & 1.52 & 1.30 & 1.28 \\
\hline SE & 0.25 & 0.25 & 0.26 & 0.38 & 0.47 & 0.50 & 0.57 & 0.70 & 0.87 \\
\hline FI & 0.28 & 0.33 & 0.36 & 0.38 & 0.41 & 0.52 & 0.61 & 0.70 & 0.79 \\
\hline NL & 0.11 & 0.14 & 0.17 & 0.19 & 0.24 & 0.31 & 0.37 & 0.49 & 0.58 \\
\hline PT & 0.19 & 0.22 & 0.27 & 0.30 & 0.24 & 0.32 & 0.28 & 0.29 & 0.28 \\
\hline FR & 0.10 & 0.10 & 0.13 & 0.17 & 0.15 & 0.25 & 0.29 & 0.28 & 0.24 \\
\hline
\end{tabular}

Source: Eurostat special extracts of aggregate LFS data, version 28.8.2014. Age: 15-64

Figures 1 and $2^{4}$ illustrate the broad developments in east/west labour mobility in the post-2004 enlargement period, displaying developments in population

4. In this section we discuss the broad developments in labour mobility and show working age population stocks instead of employment stocks in order to provide a more complete picture. As recent EU cross-border labour mobility for the most part concerns labour seeking employment, EU10 employment and population stocks are strongly linked. 
stocks separately for EU8 and EU2 migrants. Figure 1 shows an initial marked increase of the EU8 migrant population in the two receiving countries (United Kingdom and Ireland) that opened up their labour markets from the beginning while offering, at the same time, a comparatively favourable labour market situation for the absorption of immigrant labour. ${ }^{5}$ The negative impact of the crisis on post-2008 labour migration from central and eastern European countries, however, is visible particularly in Ireland, which was especially hard hit. In the United Kingdom, EU8 population stocks flattened out between 2008 and 2009 but already picked up again from 2009 onwards.

At the same time, Germany - a traditional destination country for CEE migrants but which made use of transitional measures up until May 2011 shows a steady but more moderate growth in its EU8 population up until 2010. Thereupon the growth becomes more steep, which can be linked both to the end of transition measures and recent comparatively positive labour market developments (Figure 1). Austria, another traditional destination country for central and eastern Europeans - also due to its geographic location and favourable economic conditions - shows slow increasing trends in EU8 population stocks, though from a high initial level (Table 1) up until 2011, when transition measures expired and then marked increases.

Figure 1 EU8 population in selected EU15 countries, 2005-2013 ('000; stocks)

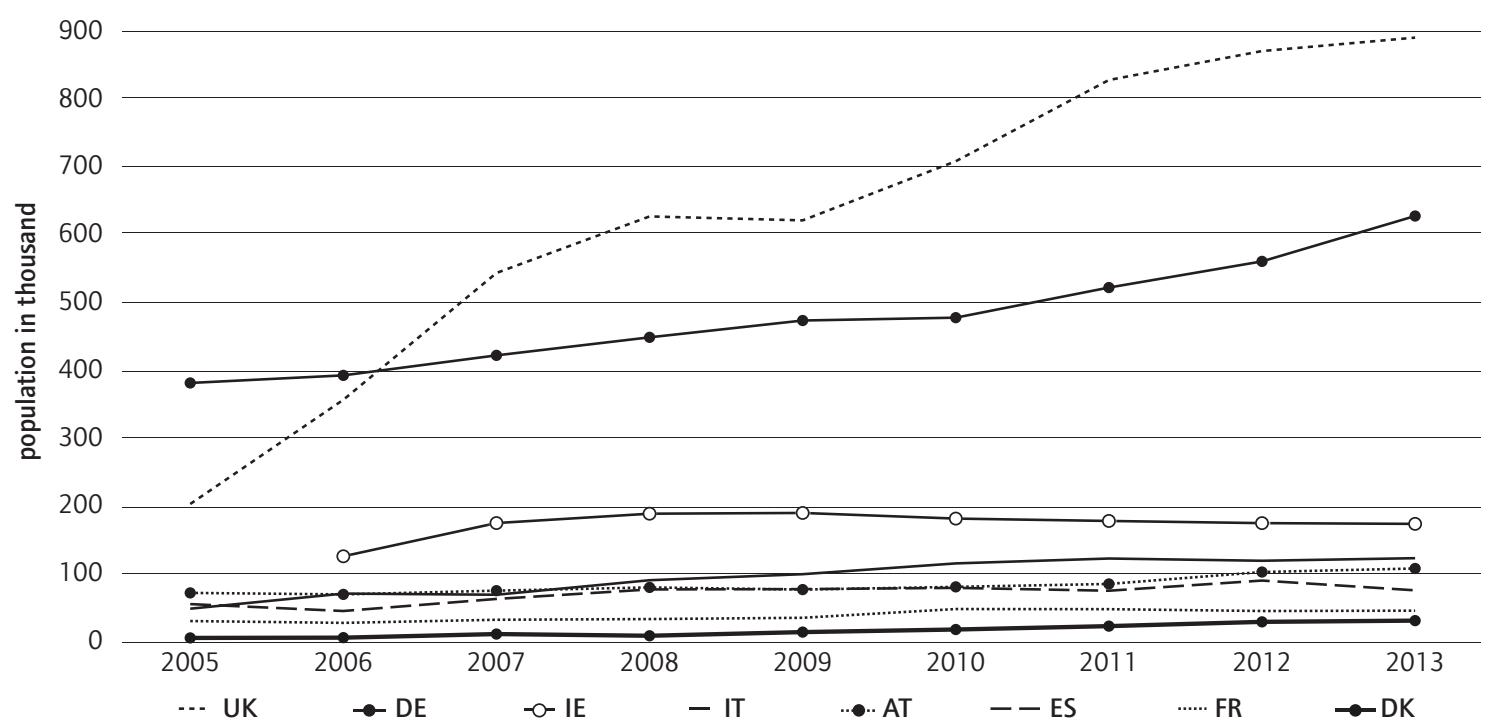

Note: Migrant workers from Malta and Cyprus are included in this figure but their numbers are negligible. Source: European Labour Force Survey. Age: 15-64

5. An illustrative example with regard to the importance of the labour market situation as a pull factor is the difference in migration inflows to Nordic countries upon EU enlargement. A more favourable labour market situation and higher wages meant that in particular Norway (and to a smaller degree also Denmark) was considerably more attractive to citizens from new EU member states than Sweden which was the only Nordic country that had opened its labour market fully to EU8 citizens upon enlargement (Lundborg 2009). 
As Figure 2 shows, there was also a growing intensity of population flows from Bulgaria and Romania (EU2). While for EU8 migrants the United Kingdom and Germany were the most popular destinations, for EU2 migrants Spain and - in particular - Italy were the most popular. Both geographic and language proximity - the latter for Romania only - can be put forward as explanation. Moreover, the United Kingdom and Germany kept transition measures for EU2 migrants in place for the full seven-year period, whereas Spain already abolished them after the first phase, but reintroduced them again for Romanian workers in mid-2011. Italy made use of transition measures until the end of the second phase (December 2011) but did not require a work permit in a number of sectors in which migrant labour is particularly important (for example, agriculture, domestic work, care services, seasonal work). The impact of the crisis on the Italian labour market has not halted a steeply increasing EU2 migrant population. On the other hand, in line with having been strongly affected by the crisis, the initial steep increase in EU2 migrants in Spain flattened out and decreased after 2009, with a slight recovery very recently. The large stocks of EU2 migrants in a number of EU15 countries also have to be seen in light of the enormous economic (for example, wages) and social differences between Bulgaria and Romania, and the EU15 countries.

Figure 2 EU2 population in selected EU15 countries, 2005-2013 ('000; stocks)

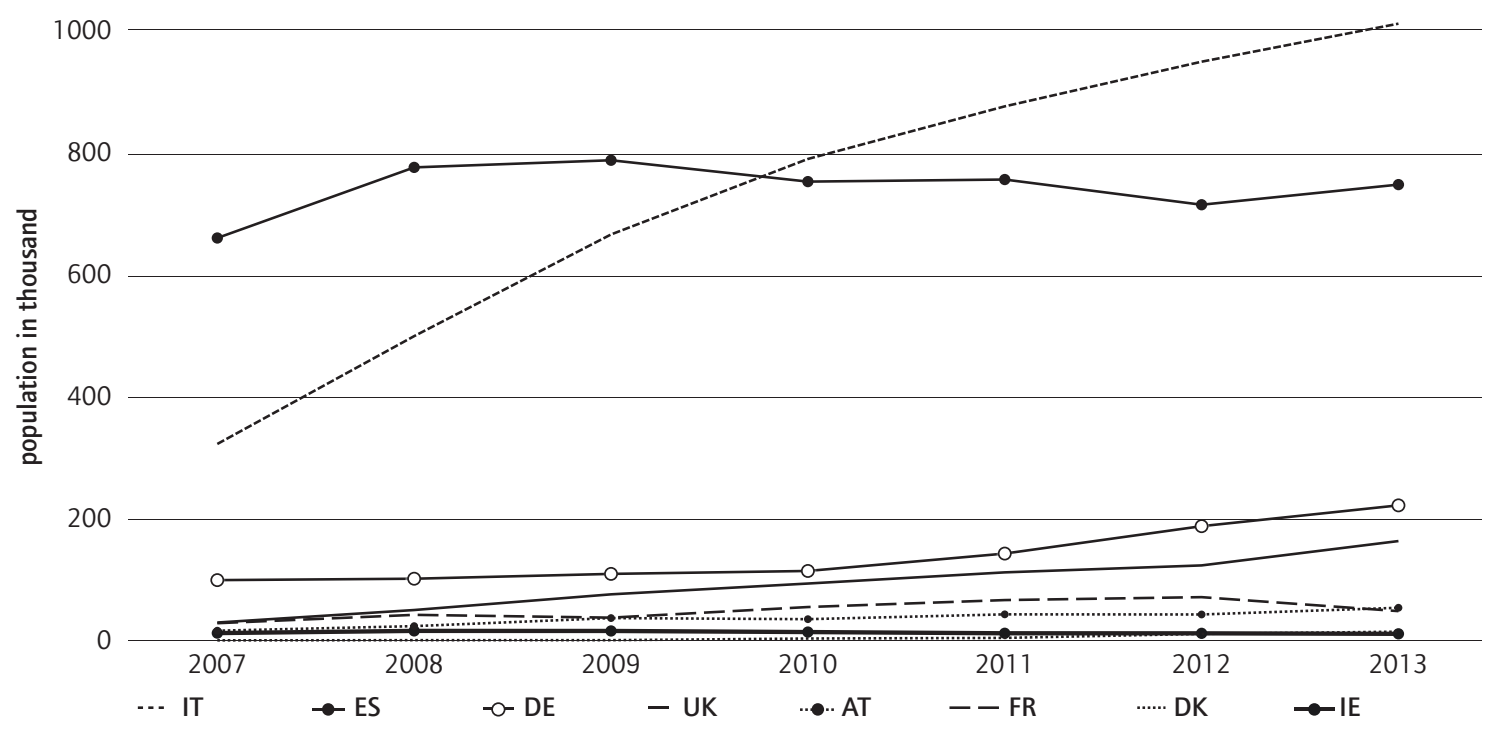

Source: European Labour Force Survey. Age: 15-64

\subsection{Sending-country labour-market performance and impact on mobility}

Not only receiving countries but also sending countries differed markedly with regard to the impact of the crisis on their labour markets. Poland, the country with the largest migration outflows in absolute terms, did comparatively well, 
being the only country not to experience an output shock, whereas - in particular - the Baltic countries experienced huge increases in unemployment and declines in employment particularly during the initial phase of the crisis, with corresponding effects on labour mobility. Indeed, during the crisis temporary reductions for some EU8 and, particularly, Polish migrants (with signs of return migration but also transmigration ${ }^{6}$ ) were observed. Fihel and Anacka (2012) show that highly skilled workers were not prone to move back to their home countries, a typical returnee profile being a middle-aged rural dweller with a low level of education. This finding indicates, further, that previous brain-drain concerns expressed by sending countries may not have eased off during the crisis. On the other hand, Hazans (2012) finds, in line with the economic situation, that in Latvia and Estonia the role of push factors (especially unemployment but in Latvia also general dissatisfaction) increased during the crisis, showing also that low-skilled persons disproportionally affected by lay-offs became over-represented among emigrants. For Romania, Stan and Erne (2014) refer to development patterns of post-communist Romania as background for the unfolding migration waves, first in the 1990s, then in the post-enlargement period after 2007. Complex combinations of both push and pull factors were also observed, with onward migration from formerly very attractive receiving countries that were hard hit by the crisis - such as Ireland - to destinations with better labour market prospects such as Norway, which saw the share of EU10 migrant population increase tenfold between 2007 and 2013 (European Labour Force Survey, not shown; on Norway see also Friberg and Eldring 2013).

As regards the direct impact of the crisis on labour market outcomes, EU10 migrants were harder hit in the majority of EU15 countries and acted, at least partially, as labour market buffers. This can be illustrated by changes in unemployment rates for nationals and EU1O migrants in receiving-country labour markets.

As Figure 3 illustrates, unemployment, traditionally higher among EU10 migrants in almost all EU15 countries, increased disproportionately for EU10 migrant workers as compared with the national population, particularly in Ireland, Greece and Spain. France and Sweden showed inverse trends, with EU10 migrant workers, in contrast to nationals, improving their unemployment rates, though from a higher initial level as compared with national population (recall that Sweden and particularly France have comparatively few EU10 migrant workers in their labour markets).

As for employment rates (ELFS data, not shown) in the majority of EU15 countries, at the start of the crisis these were higher among EU10 migrants than among nationals. Both groups saw declines in employment rates in the majority of EU15 countries but the declining trend was stronger for EU10 migrants who were, for example, considerably more affected by declining employment in Denmark, Ireland and Portugal.

6. Transmigration (or circular migration) covers a form of mobility that takes place from one country to another, not necessarily starting from the home country. 
Figure 3 Development of unemployment rates of nationals and of EU10 citizens: 2007, 2010, 2013 (in \%)

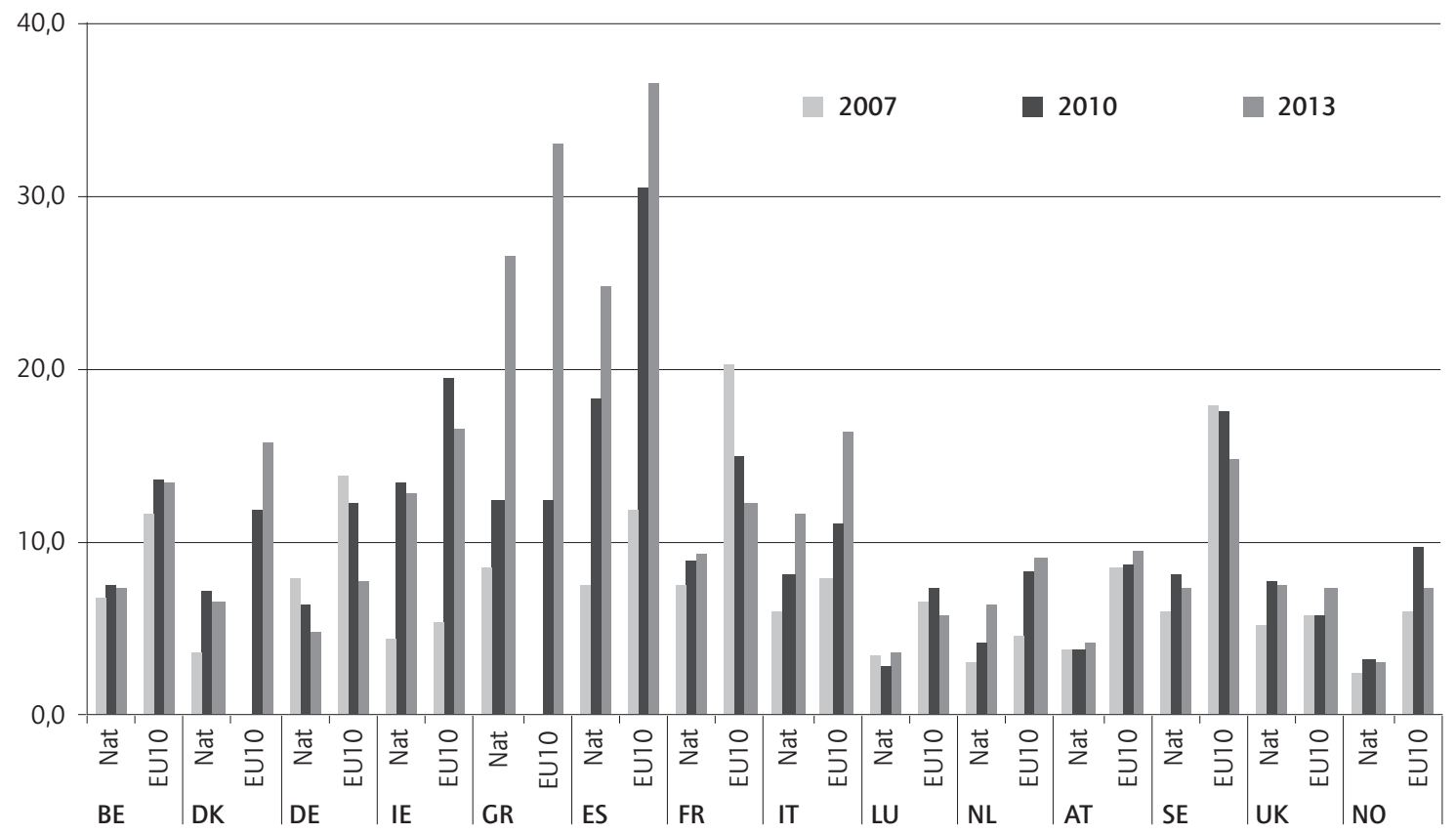

Note: Several countries have missing or incomplete data on EU10 nationals. Source: European Labour Force Survey.

The greater vulnerability of EU10 workers in the crisis reflects, among other things, the considerably higher concentration of such workers in sectors disproportionately affected by the slump in output (see also Section 3); job losses were, for example, extremely heavy in construction, which shed millions of jobs in the EU15 during the crisis and is a sector with a high concentration of EU1O workers.

Migrant workers also tend to work more often on short-term contracts and have, on average, shorter job tenure (last in, first out rule) and may also be subject to discrimination in hiring and lay-offs (compare OECD 2009: 19-25; OECD 2013 chapter 4).

In contrast to popular opinion in a number of member states, taken advantage of by populist and, more and more, also by centre parties, Giulietti finds for the EU that in only a few countries was the proportion of immigrants who receive any type of welfare support higher than that of natives, even after accounting for diverse characteristics of immigrants (Giulietti et al. 2013). For the United Kingdom, Dustmann and Frattini (2014) find that in the period between 1995 and 2011, EU immigrants who resided in the United Kingdom in any of these years were generally less likely than natives to receive state benefits or tax credits and also less likely to live in social housing than natives in the same region. This is not surprising given that recent EU migrant workers have very high employment rates, also compared with nationals in the 
receiving country labour markets (European Labour Force Survey, not shown). Moreover, while they in principle have the same rights to unemployment benefits as natives, in practice they are likely to be covered to a lesser degree due to a lack in awareness of rights and their stronger likelihood of being in atypical forms of employment, as shown for Polish workers in Oslo and Copenhagen - but not in Reykjavik - by Friberg et al. (2014).

As we have seen, although equal treatment exists in principle, in practice migrant workers are on average in a more vulnerable situation than nationals.

In spite of this, their earnings are usually substantially higher than what they could have earned back home, which at least in the short run puts them in a better situation. But what about the longer term? Can they, for example, make use of their skills and thus live up to the Commission's expectation of better labour allocation? 


\section{EU10 migrant labour and skills mismatch: brain drain, brain gain and brain waste}

In order to get a fuller picture of the potential of recent EU labour mobility we will now discuss the skills/occupation mismatch. While migrant labour is often discussed with regard to skills and education, the debate depends fundamentally on one's perspective. From a sending-country standpoint, the literature is often concerned with the brain drain, which occurs when highly qualified people or workers with specific skills needed in the local labour market leave the country in disproportionately large numbers.

An important 'stylised fact' is that EU10 countries have significantly higher shares of medium and high skilled persons in their working age population than the EU15 countries. The share of persons who have completed at least upper secondary education is almost 20 percentage points higher in the EU10 than in the EU15. Moreover, young migrants, who on average have higher education levels, have dominated post-accession cross-border movements. This implies that post-2004 migration is qualitatively different from previous migration waves (European Integration Consortium 2009).

In light of increasing human capital investment in the vast majority of EU10 countries, as evident for example in the increasing trend in enrolled tertiary education students, the brain drain hypothesis has been challenged for some new member states and it has been suggested that it should be interpreted rather in terms of a brain 'overflow' (a form of brain waste): in other words, a lack of employment opportunities in the home labour markets commensurate with the high skills that young people, in particular, have to offer (see, for example, Fihel et al. 2007; Kaczmarczyk and Okólski 2008).

From a receiving-country perspective the discussion is about brain gain versus brain waste. A brain gain occurs when migrant workers are recruited to fill gaps in the high skilled segment (for example, doctors) or in specific occupations experiencing shortages (for example, nurses or IT experts). In the context of east/west EU labour mobility specific programmes to attract high skilled labour and retain graduates from EU10 countries have been important in, for example, Germany and Austria, or more recently in the United Kingdom and Germany for workers from Romania and Bulgaria, as part of their transitional measures (OECD 2010: 42-58). A form of brain gain can also apply from a sending country perspective if the migrant workers return to their home country with improved skills and qualifications (for example, language skills).

Over-qualification (sometimes termed 'brain waste') describes a situation in which migrant workers are employed in jobs that are substantially below their 
skill level. This was a key finding of our earlier study (Galgóczi, Leschke and Watt 2009 and 2012). From a European perspective this risks misallocating scarce human capital and, on the individual level, challenges the hypothesis that returning migrant workers will have improved their human capital. This finding also challenges the expectations of the European Commission (2012) that increased labour mobility contributes to better labour allocation in times in which labour market opportunities vary strongly from one member state to the other.

A conclusion from the existing literature is that in most cases neither the 'brain drain' nor the 'brain gain' will have a strong overall impact on labour markets and the economies of the sending and receiving countries. However, for small sending countries with large outflows and in certain sectors (for example, medical staff) it may be a cause for concern.

In the following we discuss the skills composition of EU migrant workers as compared with nationals in selected EU15 countries and briefly present some findings from the literature on skills/occupation mismatch. We then substantiate our argument by presenting some data on sectoral distribution of EU migrant workers as compared with nationals.

\subsection{Skills composition of EU10 workers and nationals}

Looking at the age group 15-64, the skills composition of EU8 and EU2 migrants as well as nationals differs considerably between receiving countries, as Figure 4 shows. Comparing the skills profiles of migrant workers with nationals quite similar outcomes of all three groups can be observed across the majority of receiving countries and especially in France and the United Kingdom. Only in Spain do the profiles of EU8 and EU2 migrants and nationals differ strongly. Spain seems to have attracted highly qualified EU8 migrants (in relatively low absolute numbers, however, as in Spain EU8 migrants make up only a fraction of the EU10 population), whereas EU2 nationals in Spain display a lower education profile than nationals. Overall, Ireland, the United Kingdom and France seem to have been more successful in attracting highly qualified EU10 migrants, while the share of highly qualified EU8 and EU2 migrant workers is particularly low in Italy - and thereby not much different from the national population. The overall impact of exemptions with regard to work permits for certain occupations and in some cases for university graduates as part of the transition measures in attracting highly qualified EU10 workers is hard to assess as it has been shown that countries which opened their labour markets from the start were more successful in attracting young and high qualified EU migrant labour (Fihel and Okolski 2009).

Despite these profiles that do not differ much from nationals in many cases, a number of recent studies show that post-2004 migrants from the new member states are employed well below their skill levels and thus that the returns to education are very low ('brain waste'). The European Integration Consortium (2009: 97-103) illustrates this for the United Kingdom, as do the chapters in 
Figure 4 Skill proportion in total employment: nationals, EU8 and EU2 citizens, 2013

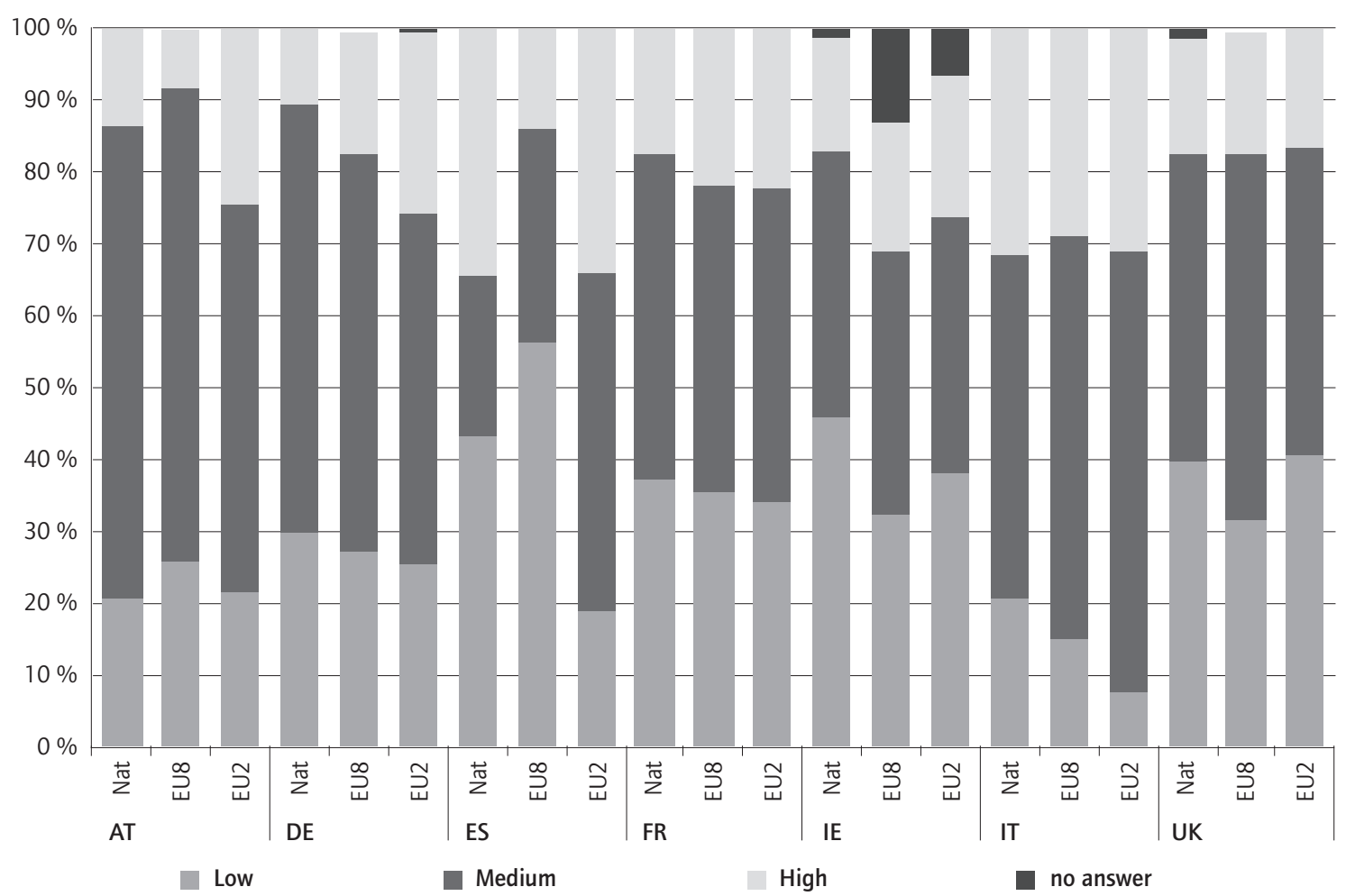

Note: Denmark could not be included in this figure as the majority of EU2 and EU8 nationals in Denmark provided no answer to this question.

Source: Eurostat special extracts of aggregate LFS data, version 28.8.2014. Age: 15-64

Kahanec and Zimmermann (2010) and Galgóczi, Leschke and Watt (2009 and 2012) for a range of receiving countries. Bettin (2012: 60), for example, shows, on the basis of national labour force survey data, that the skills/occupation mismatch among EU10 migrant workers is substantial in both the United Kingdom and Italy, with disproportionate shares of migrant workers in both countries working in low qualified jobs. For example in the United Kingdom, 79.4 per cent of nationals and 82 per cent of EU15 citizens with tertiary education were employed in 2010 as whitecollar employees, but only 32.3 per cent of EU8 (38.5 per cent of EU2) workers with similar qualifications had a whitecollar job. The 'brain waste' hypothesis is also confirmed by Dølvik and Eldring (2008: 76-77) for Baltic and Polish migrants in the Nordic countries. 


\subsection{Sectoral distribution of EU10 labour in major EU15 receiving countries}

A glance at the sectoral composition of EU8 and EU2 migrants as compared with nationals in major EU15 receiving countries ${ }^{7}$ adds additional evidence of the skills/occupation mismatch. We focus on the six economic sectors which are on average, according to labour force survey data, most important for EU migrant labour: hotels and catering, household services, administrative and support service activities, agriculture, construction and manufacturing. ${ }^{8}$ These sectors are overwhelmingly characterised by manual labour, not for the most part requiring a higher education.

The distribution of EU10 migrants and nationals shows quite different patterns. With individual differences in scope it is true for all receiving countries discussed here that nationals are under-represented in the sectors where migrants are most likely to be found. The United Kingdom and Spain show this trend most clearly, as between 70 per cent and 80 per cent of EU10 migrants are concentrated in the six sectors specified above, while for the national population the shares are between 30 per cent and 40 per cent. It is important to note that the survey data used here are likely to under-represent migrant workers in certain sectors and in particular those characterised by seasonal employment or commuter employment ${ }^{9}$ (for example, agriculture) and those disproportionally characterised by undeclared work (for example, household services).

By way of example Figures 5 a to 7 a display the sectoral concentration of the three population groups in the six sectors for Germany, the United Kingdom and Spain for 2013. Figures 5b to $7 \mathrm{~b}$ show the changes in employment by population group in the selected sectors between 2008 and 2013 for the three receiving countries. While in Germany hotels and catering, administrative and support services, construction and manufacturing all carry similar shares of migrant workers, in the United Kingdom, construction clearly dominates for EU2 workers, while for EU8 workers construction and manufacturing are the most important (Figures 5 a and 6a). In Germany, employment in all the chosen sectors grew between 2008 and 2013, particularly for EU2 workers (Figure $5 b$ ). The same is true for the United Kingdom, although with little growth (and a slight decline in household services) for EU8 workers, but substantial increases for EU2 workers, especially in food/catering and administration/support services (Figure 6b).

7. We analysed sectoral data for Austria, Denmark, Germany, Italy, Ireland, Spain and the United Kingdom (figures available on request). The general statements made in the following paragraphs prove true for all these countries. Due to reasons of space we present and discuss more detailed findings only for Germany, Spain and the United Kingdom, countries that display particularly interesting trends.

8. As, for example, waiters and bar tenders, household cleaners and carers and harvest help in agriculture.

9. Commuter employment includes diverse activities; for examples and detailed analysis in an EU mobility perspective see Huber (2012). 
Figure 5a Germany: sectoral distribution of nationals, EU8 and EU2 migrants, choice of sector, 2013

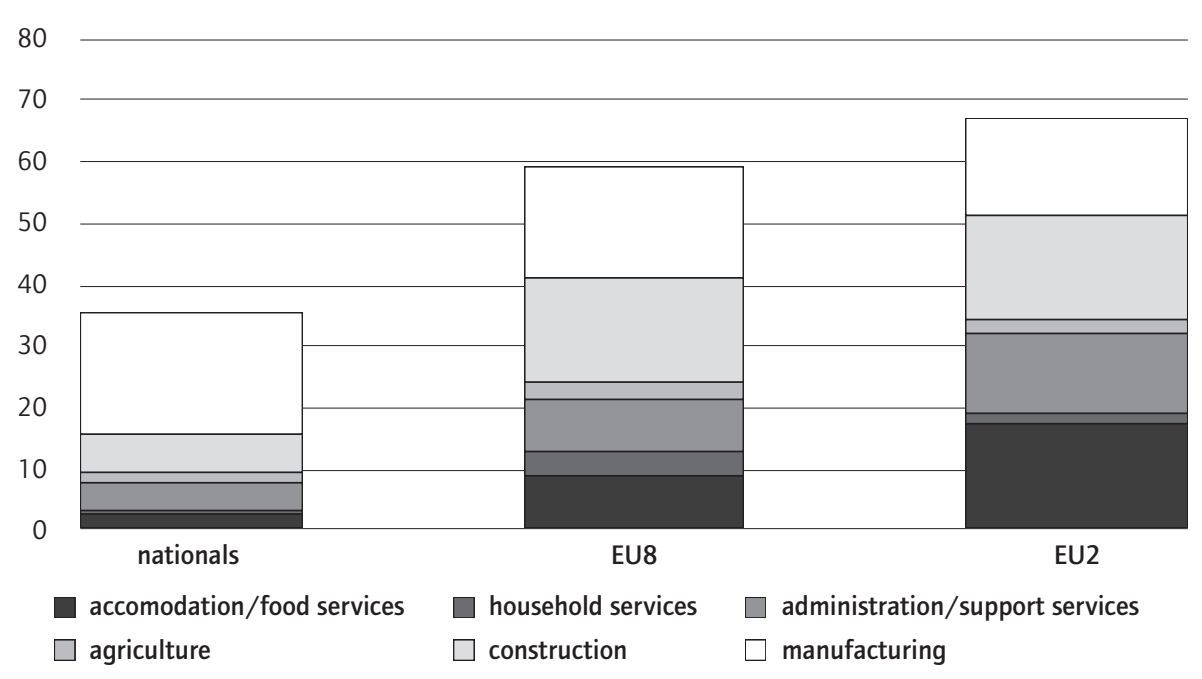

Note: Information on agriculture missing for EU2.

Source: Eurostat special extracts of aggregate LFS data, version 28.8.2014. Age: 15-64

Figure 5b Germany: change of sectoral employment for nationals, EU8 and EU2 migrants, 2013/2008 (index in \%)

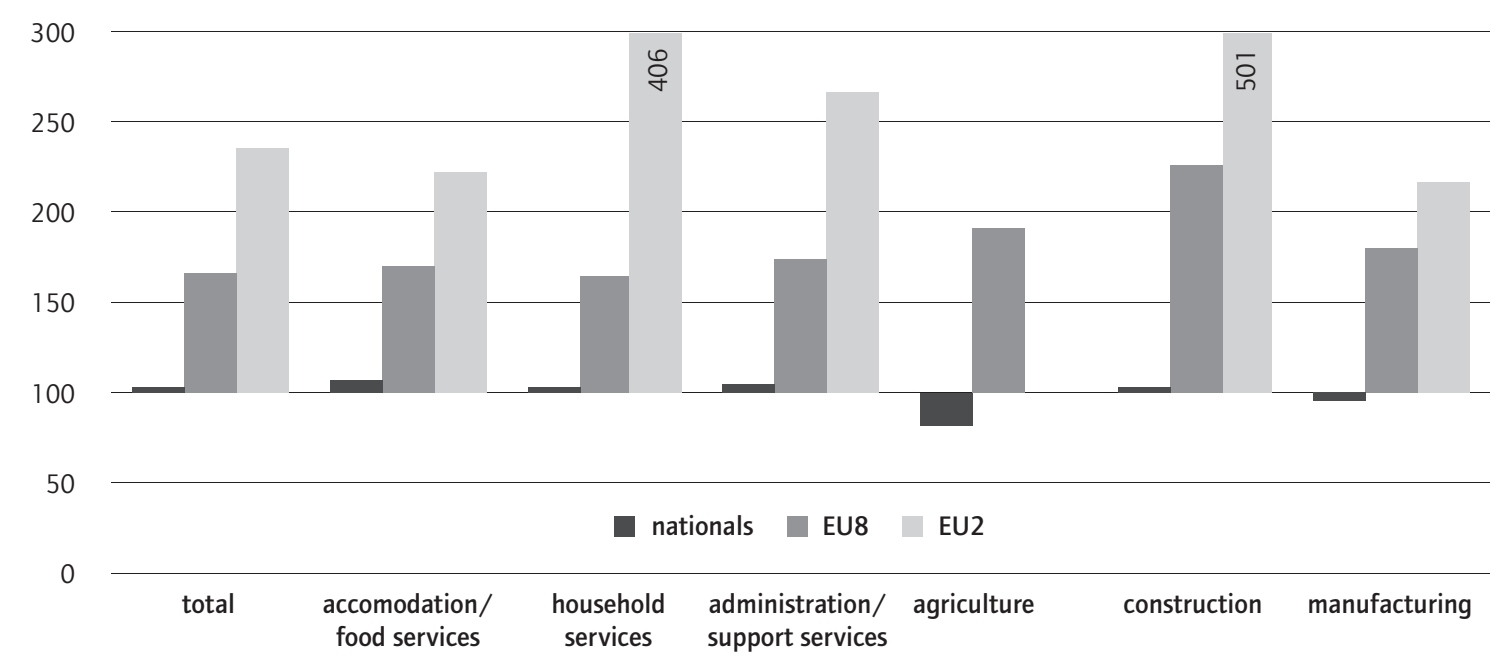

Source: Eurostat special extracts of aggregate LFS data, version 28.8.2014. Age: 15-64 
Figure 6a United Kingdom: sectoral distribution of nationals, EU8 and EU2 migrants, choice of sectors, 2013

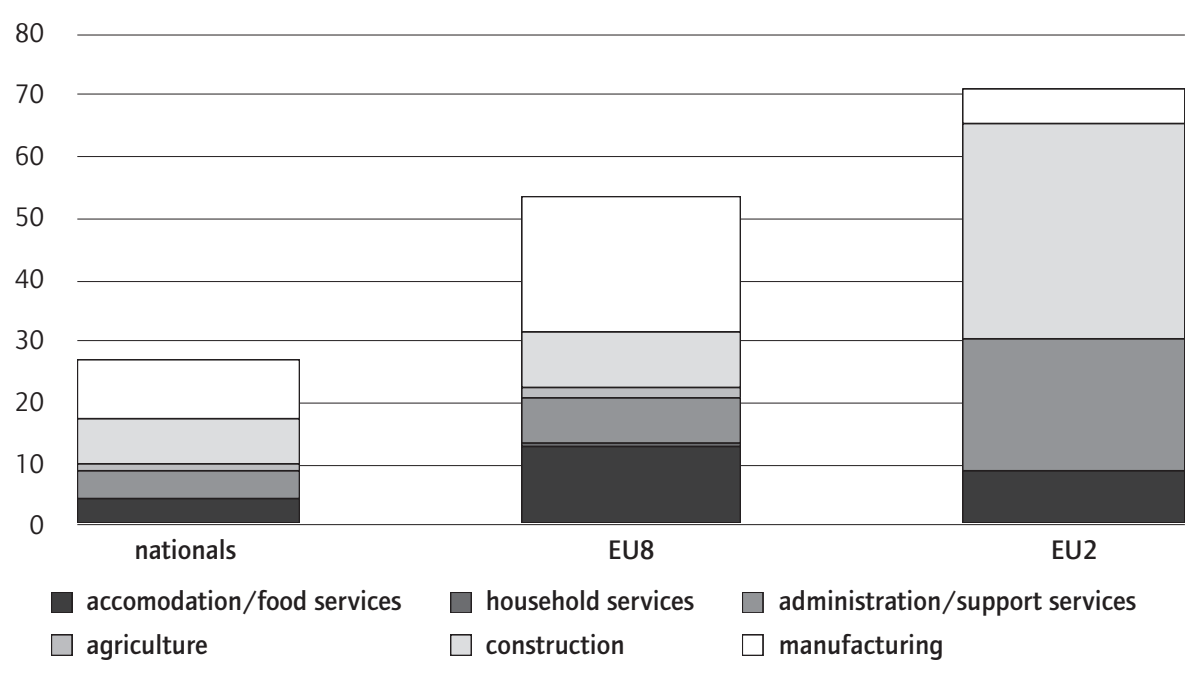

Note: Information on activities of private households as employers and agriculture missing for EU2 workers in 2013.

Source: Eurostat special extracts of aggregate LFS data, version 28.8.2014. Age: 15-64

Figure $6 \mathrm{~b}$ United Kingdom: change of sectoral employment for nationals, EU8 and EU2 migrants, 2013/2008 (index in \%)

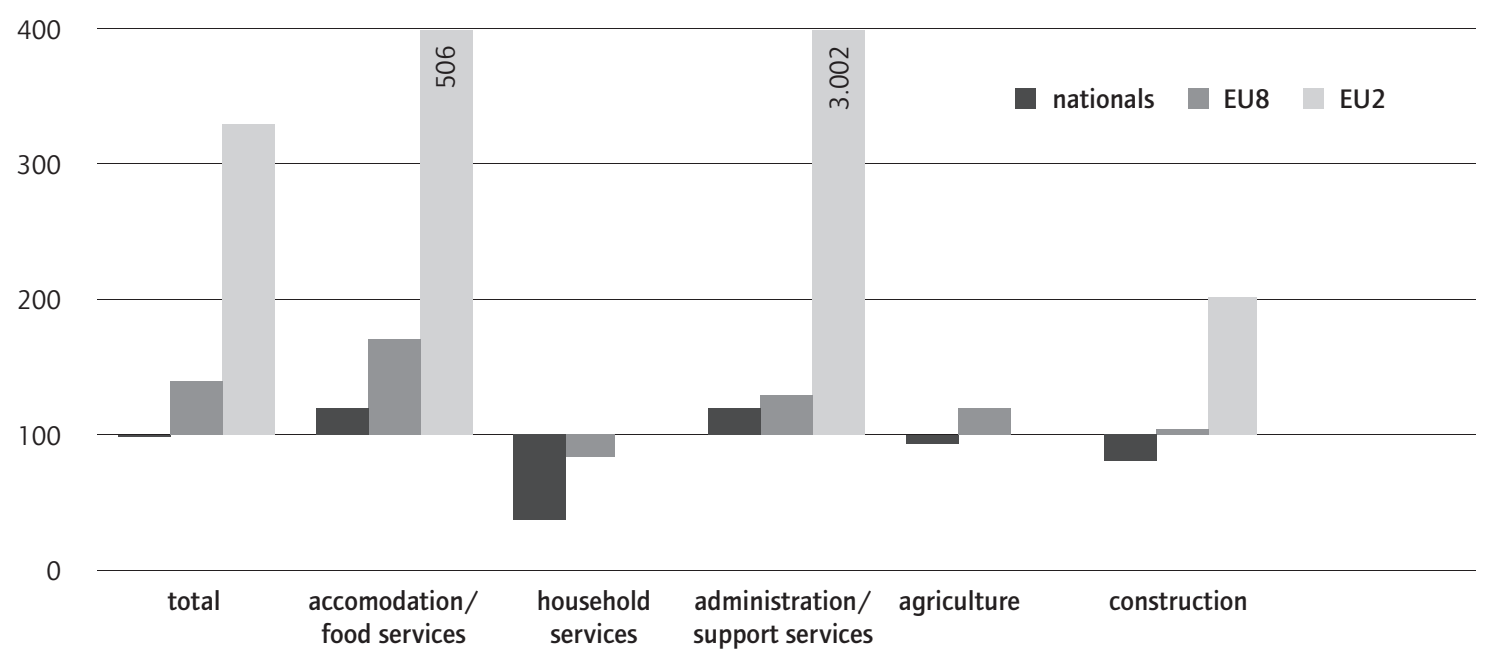

Source: Eurostat special extracts of aggregate LFS data, version 28.8.2014. Age: 15-64 
Figure 7a Spain: sectoral distribution of nationals, EU8 and EU2 migrants, choice of sectors, 2013

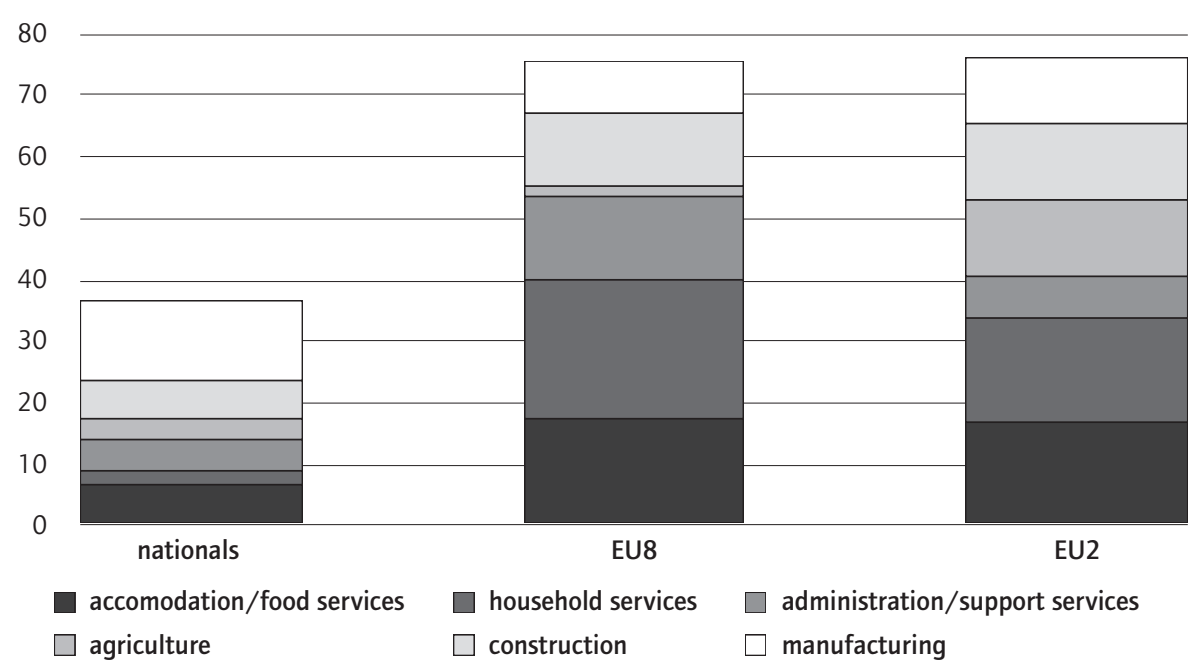

Source: Eurostat special extracts of aggregate LFS data, version 28.8.2014. Age: 15-64

Figure 7b Spain: change of sectoral employment for nationals, EU8 and EU2 migrants, 2013/2008 (index in \%)

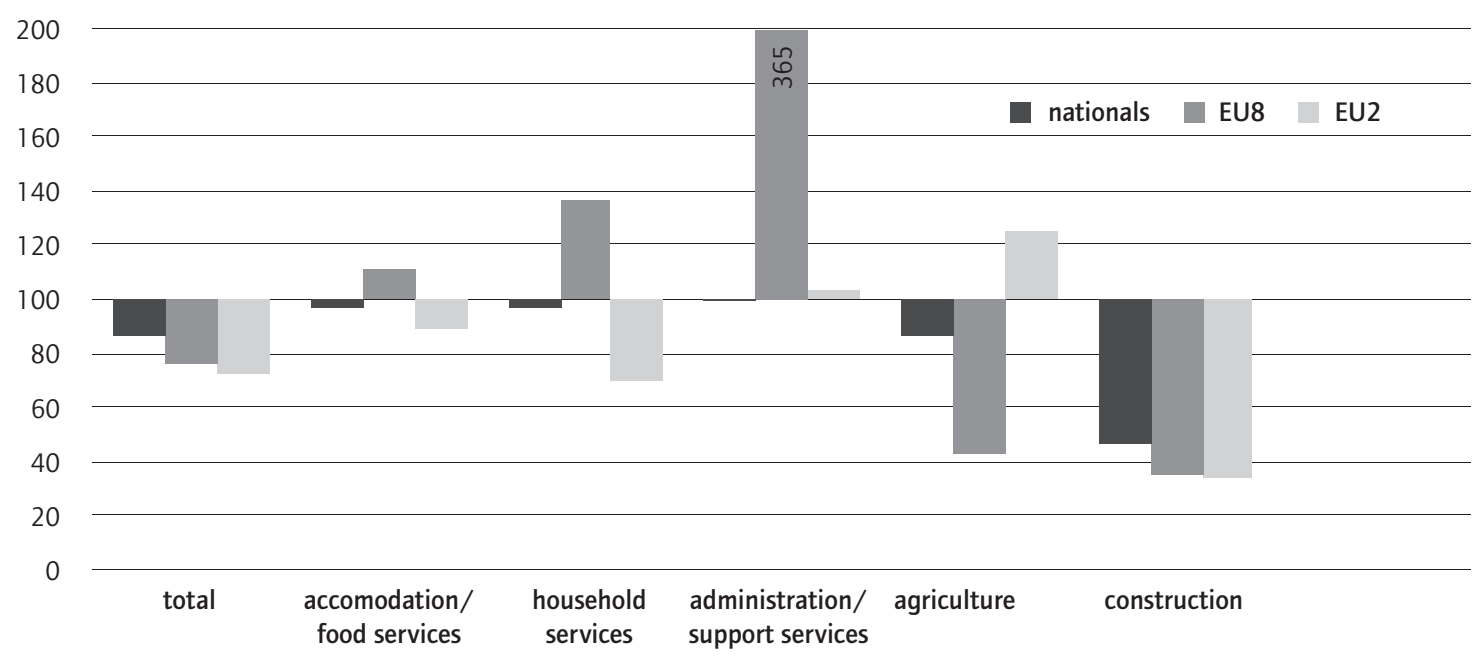

Source: Eurostat special extracts of aggregate LFS data, version 28.8.2014. Age: 15-64 
Spain deserves special attention given its previously high attractiveness for migrant workers, particularly from EU2 countries and the subsequent catastrophic labour market performance during the crisis. The sectoral distribution of EU8 and EU2 labour compared with that of nationals shows similar characteristics to other major EU15 receiving countries; EU10 migrants are overrepresented in hotels and catering, agriculture, construction and household services. The main difference is that the share of private household services for EU10 migrants is substantially higher in Spain than in the United Kingdom and Germany (Figure 7a) (the same is true for Italy, figure not shown). Migrant workers are used in these sectors to compensate for deficient welfare state services with regard to child and elderly care (Domínguez-Mujica et al. 2015).

Also, in contrast to the other two countries, in Spain the crisis led to losses in both absolute and relative terms (Figure $7 \mathrm{~b}$ ) and the dynamics of change during the crisis were more pronounced. Both EU1O migrants and nationals have been heavily affected by the crisis and their employment shows losses in all major sectors, particularly in construction and manufacturing. In the latter two sectors the employment losses are greater for EU10 migrants than nationals, who are also heavily affected (a 'lose/lose' case). Gains for EU10 migrants can be identified in a number of sectors. In household services, employment of EU8 migrants grew during the crisis, but fell for the EU2, probably as an effect of the re-introduction of transitional measures for EU2 citizens in 2011. In agriculture the opposite trend prevailed, while in administrative and support services a high increase in EU8 employment occurred, although absolute numbers are relatively low.

When examining the skills characteristics of EU10 migrant workers in the EU15, it has been emphasised that the educational attainment of the EU10 immigrant population compared with that of the national population tends to be similar (or in certain cases higher). However, skills/occupation mismatch is an important characteristic of post-2004/2007 intra-EU migration; this claim has been substantiated by the current sectoral distribution of migrant labour, which focuses overwhelmingly on sectors that do not require a higher education.

Judging from the recent literature and the above analysis, post-enlargement east/west labour mobility has not contributed to better human capital allocation. Indeed, the decision to emigrate seems to be driven rather by absolute differences in wage levels across countries than by the relative returns to skills. The resulting loss of human capital in a longer term perspective is a clear indication that the potential of the freedom of labour in a single European labour market is not being exploited to the full. 



\section{Conclusions and policy recommendations}

Recent and current east/west post-enlargement migration within the EU, as described in this working paper, is taking place in a rapidly changing economic and regulatory environment. The process overall includes various forms of human and labour mobility, including regular employment, mobility under the services directive, posted work and commuting. Since the 2004 and 2007 enlargement waves, push and pull factors affecting the behaviour and decisions of migrants have - accordingly - swung to and fro, subject to rapid and often contradictory forms of change.

The economic and wage convergence between sending and receiving countries that was characteristic of the initial period after accession was pulled up short by the crisis. However, as regards the impact of the crisis, the dividing line has been not between sending and receiving countries but between one group of European countries that were particularly severely affected by the crisis (especially the Baltic countries, Spain and Ireland) and another group of countries (for example, Germany and Poland) that were much less affected.

Intra-EU labour mobility appears to be very responsive to changes in the regulatory and macroeconomic environment. The shock of the crisis was not just a general test of labour markets throughout Europe but provided considerable insight into the relative position and role played by migrant labour. Migrant workers were often more severely affected as, because of their more precarious labour market situation, it was comparatively easier to use them as a labour market buffer in receiving countries.

EU10 migrants are similar to nationals in EU15 countries regarding their educational attainments. Our analysis, in line with previous research, shows, however, that a characteristic feature of recent EU10 migrants turns out to be skills/occupation mismatch. This under-utilisation of human capital is one of the greatest challenges that intra-EU labour mobility has faced in recent years. The phenomenon can also be seen as a policy failure both at EU and national level with regard to improving the efficiency of cross-border labour mobility. The second major aspect of the underperformance of cross-border labour mobility is the substantial vulnerability of mobile workers. Whereas equal treatment is the main principle, due to a lack of implementation and circumvention strategies under services mobility, for example, it does not materialise in practice. It is still a major shortcoming of the emerging single European labour market that social and working standards do not apply equally to different channels of mobility. Compared with regular employment posted work and self-employment still open the door to social dumping. Even 
within regular employment EU10 labour is more subject to precarious forms of employment and EU1O workers are often not aware of their rights.

In sum, post-enlargement east/west labour mobility has not proved to be a lever of better labour allocation towards a single European labour market. Instead, the contribution of migrant labour to labour market flexibility has proved to be controversial not only for the migrants themselves but also for receiving-country labour markets (for example, recall the recent debates on potential 'misuse' of welfare benefits in countries such as the United Kingdom, Denmark and Germany). These lessons are particularly important given that increased labour mobility within the EU and the euro zone - including the recent wave of south/north migration flows - are, at least by the European Commission, more and more seen as an additional crisis management tool.

The potential of a single European labour market can lead to a better allocation of labour only if a wide range of supporting policies facilitate this. What can European and national policymakers thus do to make the best out of crossborder labour mobility and, at the same time, to minimise its negative side effects and thereby also improve its perception?

To some extent, the announced Labour Mobility Package in the Commission's 2015 Working Programme (European Commission 2014) can be seen as a good start. The announced main objectives of the package - supporting labour mobility and tackling abuse by means of better coordination of social security systems, the targeted review of the Posting of Workers Directive and an enhanced EURES - are essential elements. The anomalies of labour mobility and in particular the role of temporary staffing agencies, the misuse of posted work (as documented by a number of ECJ court cases) and self-employment as a substitute for regular employment need effective policy responses in order to avoid social dumping and to protect mobile workers. This is particularly true with regard to a number of issues that emerged in the context of the so-called 'benefit tourism' debate, where potential loopholes need to be closed, but discrimination against mobile workers, as currently propagated by the United Kingdom ${ }^{10}$ and recently supported by Germany, should clearly be avoided. Coordinating social security provisions among member states and ensuring that all mobile workers are fairly covered is thus a key element in putting the principle of equal treatment into practice. The overall objective should be to ensure that 'fair mobility', a key claim and principle promoted by European trade unions, prevails. To put the equal treatment principle into practice a number of targeted policies are necessary. The cross-border role of national public employment services could be further strengthened. Also wider awareness of European Commission initiatives, such as the European Job Mobility Portal, EURES or the 'Your Europe' website, which provides a range

10. Restrictions in the United Kingdom were introduced in 2014, preventing new migrants from EEA countries claiming out-of-work benefits for the first three months of their residency, and introducing a minimum earnings threshold to qualify for benefits. In addition, since 1 April 2014, EEA migrants have been unable to claim housing benefit unless they are in work. 
of information - including on benefit rights - for mobile EU citizens and a better linking of those sites would be beneficial. Mutual recognition of qualifications should not remain a declared objective but needs to be implemented as it also needs to be affordable (in terms of the administrative burden and the cost imposed on mobile workers). National contact points set up by member states to facilitate mobility, by providing information, assistance and advice to mobile workers, should also address the vulnerability of mobile workers to potential abuse and discriminatory practices. In this regard the good practice of the European Trade Union Confederation's (ETUC) initiative 'union-migrant.net'11 and migrant contact points should be taken into account, such as the German Trade Union Confederation's (DGB) 'fair-mobility' project. ${ }^{12}$ Moreover it is important to establish an EU platform against undeclared work that could also be seen as an initial step towards a European labour inspection agency.

Finally, municipalities on which particular burdens are imposed due to increased immigration need to have access to support from their national governments but also from the European Social Fund, not only on an ad hoc basis, but systematically.

11. http://social.unionmigrantnet.eu

12. http://www.faire-mobilitaet.de/en/ueber-uns 



\section{References}

Arpaia A., Kiss A., Palvolgyi B. and Turrini B. (2014) Labour mobility and labour market adjustment in the EU, Economic papers 539, Brussels, European Commission.

Ahearne A., Brücker H., Darvas Z. and von Weizsäcker J. (2009) Cyclical dimensions of labour mobility after EU enlargement, WP 2009/2, Brussels, Bruegel. http://www. econ.core.hu/file/download/mtdp/MTDP0910.pdf

Ambrosini J.W, Mayr K., Peri G. and Radu D. (2011) The selection of migrants and returnees: evidence from Romania and implications, Research paper draft, Davis, University of California. http://economics.ucdavis.edu/people/gperi/site/papers/ the-selection-of-migrants-and-returnees-evidence-from-romania-andimplications/at_download/file

Bettin G. (2012) Migration from the accession countries to the United Kingdom and Italy: socio-economic characteristics, skills composition and labour market outcomes, in Galgóczi B., Leschke J. and Watt A. (eds.) Migration and labour markets in troubled times: skills mismatch, return migration and policy responses, Farnham, Ashgate, 47-79.

Brücker A. and Warneck W. (2010) Viking - Laval - Rüffert: consequences and policy perspectives, Report 111, Brussels, ETUI.

Cremers J. (2011) In search of cheap labour in Europe: working and living conditions of posted workers, CLR Studies 6, Amsterdam, European Institute for Construction Labour Research.

Dølvik J.E. and Eldring L. (2008) Mobility of labour from new EU states to the Nordic Region: development trends and consequences, Copenhagen, Nordic Council of Ministers.

Domínguez-Mujica J., Díaz-Hernández R.F. and Parreño-Castellano J.M. (2015) Gender, migration and household services in Spain. http://www.researchgate.net/ publication/274194472_Gender_migration_and_household_services_in_Spain

Dustmann C., Casanova M., Fertig M., Preston I. and Schmidt C. (2003) The impact of EU enlargement on migration flows, Home Office Online Report 25/03, London, Home Office. http://storage.globalcitizen.net/data/topic/knowledge/uploads/ 20100727103059705.pdf

Dustmann C. and Frattini T. (2014) The fiscal effects of immigration to the UK, The Economic Journal, 124 (580), F593-F643. doi: 10.1111/ecoj.12181

Giulietti C., Guzi M., Kahanec M. and Zimmermann K.F. (2013) Unemployment benefits and immigration: evidence from the EU, International Journal of Manpower, 34 (1), 24-38.

European Integration Consortium (2009) Labour mobility within the EU in the context of enlargement and the functioning of the transitional arrangements. http://doku. iab.de/grauepap/2009/LM_finalreport.pdf

European Commission (2010) The European Job Mobility Action Plan 2007-2010: implementation report, Brussels, European Commission.

European Commission (2011) Commission report on transitional arrangements regarding free movement of workers from Bulgaria and Romania, Press release MEMO/11/773. http://europa.eu/rapid/press-release_MEMO-11-773_en.htm

European Commission (2012) Employment and social developments in Europe 2011, Luxembourg, Publications Office of the European Union.

European Commission (2014) Commission Work Programme 2015. http://ec.europa.eu/ atwork/pdf/cwp_2015_new_initiatives_en.pdf 
Eurostat, Labour Force Survey (EU LFS), online database. http://ec.europa.eu/eurostat/ web/microdata/european-union-labour-force-survey

Fellmer S. and Kolb H. (2009) EU labour migration: government and social partner policies in Germany, in Galgóczi B., Leschke J. and Watt A. (eds.) EU labour migration since enlargement: trends, impacts and policies, Aldershot, Ashgate, 127-147.

Fihel A. et al. (2007) Labour mobility in the context of enlargement and the functioning of transitional arrangements - Country report: Poland, University of Warsaw, Centre for Migration Studies.

Fihel A. and Okólski M. (2009) Dimensions and effects of labour migration to EU countries: the case of Poland, in Galgóczi B., Leschke J. and Watt A. (eds.) EU labour migration since enlargement: trends, impacts and policies, Aldershot, Ashgate, $185-210$

Fihel A. and Anacka M. (2012) Return migration to Poland in the post-accession period, in Galgóczi B., Leschke J. and Watt A. (eds.) Migration and labour markets in troubled times: skills mismatch, return migration and policy responses, Farnham, Ashgate, 143-167.

Friberg J.H. and Eldring L. (eds.) (2013) Labour migrants from Central and Eastern Europe in the Nordic countries: patterns of migration, working conditions and recruitment practices, Copenhagen, Nordic Council of Ministers.

Friberg J.H., Arnholtz J., Eldring L., Hansen N.W. and Thorarins F. (2014) Nordic labour market institutions and new migrant workers: Polish migrants in Oslo, Copenhagen and Reykjavik, European Journal of Industrial Relations, 20 (1), 37-53.

Galgóczi B., Leschke J. and Watt A. (eds.) (2009) EU Labour migration since enlargement: trends, impacts and policies, Aldershot, Ashgate.

Galgóczi B., Leschke J. and Watt A. (eds.) (2012) Migration and labour markets in troubled times: skills mismatch, return migration and policy responses, Farnham, Ashgate.

Heinz F. and Ward-Warmedinger M. (2006) Cross-border labour mobility within an enlarged EU, Occasional Paper 52, Frankfurt am Main, European Central Bank.

Hazans M. (2012) Selectivity of migrants from Baltic countries before and after enlargement and responses to the crisis, in Galgóczi B., Leschke J. and Watt A. (eds.) Migration and labour markets in troubled times: skills mismatch, return migration and policy responses, Farnham, Ashgate, 169-208.

Holland D., Fic T., Rincon-Asnar A., Stokes L. and Paluchowski P. (2011) Labour mobility within the EU - The impact of enlargement and the functioning of the transitional arrangements, Final report of a study carried out on behalf of the Employment, Social Affairs and Inclusion Directorate General of the European Commission.

Huber P. (2012) Educational attainment and education-job mismatch of cross-border commuters in the EU, in Galgóczi B., Leschke J. and Watt A. (eds.) Migration and labour markets in troubled times: skills mismatch, return migration and policy responses, Farnham, Ashgate, 109-140.

IDEA Consult and ECORYS Netherlands (2011) Study on the economic and social effects associated with the phenomenon of posting of workers in the EU, Final report on behalf of the European Commission Directorate General Employment, Social Affairs and Equal Opportunities.

Kahanec M. and Zimmermann K. F. (eds.) (2010) EU labour markets after postenlargement migration, Berlin, Springer.

Kaczmarczyk P. and Okólski M. (2008) Demographic and labour-market impacts of migration on Poland, Oxford Review of Economic Policy, 24 (3), 599-624. 
Lundborg P. (2009) The dimensions and effects of EU labour migration in Sweden, in Galgóczi B., Leschke J. and Watt A. (eds.) EU labour migration since enlargement: trends, impacts and policies, Aldershot, Ashgate, 69-86.

OECD (2009) International Migration Outlook 2009, Paris, Organisation for Economic Co-operation and Development.

OECD (2012) International Migration Outlook 2012, Paris, Organisation for Economic Co-operation and Development.

OECD (2013) International Migration Outlook 2013, Paris, Organisation for Economic Co-operation and Development.

Stan S. and Erne R. (2014) Explaining Romanian labor migration: from development gaps to development trajectories, Labor History, 55 (1), 21-46. doi: 10.1080/ 0023656X.2013.843841 